\title{
Charophyte Communities in the Ein Afeq Natural Reserve, Israel
}

\author{
Sophia Barinova ${ }^{1, *}$, Roman Romanov ${ }^{2}$ \\ ${ }^{1}$ Institute of Evolution, University of Haifa, Israel \\ ${ }^{2}$ Central Siberian Botanical Garden of the Siberian Branch of the Russian Academy of Sciences, Russia
}

Copyright $(\mathcal{C} 2015$ by authors, all rights reserved. Authors agree that this article remains permanently open access under the terms of the Creative Commons Attribution License 4.0 International License

\begin{abstract}
First study of new locality in the Ein Afeq Natural Reserve with charophytes in the Akko Plain of Northern Israel has been implemented for revealing of algal diversity and ecological assessment of the water object environment by bio-indication methods. Altogether seventy one species of algae including two of them macro-algae Chara vulgaris Linnaeus and C. connivens P. Salzmann ex A. Braun were revealed. Chara was found in massive growth in two newest pools. Bio-indication and chemical variables characterize the pools environment as eutrophic, low- to middle organic polluted, Class II-III of water quality. Water was fresh, temperate, low alkaline, and well saturated by oxygen. Succession of algal community and higher aquatic plants shows increasing of organic pollution from 2005 to 2015 as a result of recreation impact. We can recommend the Ein Afeq pools for monitoring of natural aquatic object in the Akko Plane as reference site, and Chara vulgaris and $C$. connivens as climatic and successional indicators.
\end{abstract}

Keywords Charophytes, Ecology, Bio-indication, Ein Afeq Natural Reserve, Israel

\section{Introduction}

Diversity of the charophytes (Charales, Streptophyta) in the Eastern Mediterranean is studied in initial stage. But these macroscopic autotrophic algae may be very important components of vegetation in several types of water bodies and may be used as a bio-indicator of ecosystem state, water quality, and ecosystem recovery and reservoir management efficiency.

Charophytes easily colonize habitats in new water bodies as well as ones formed as result of disturbance. They are well-known as pioneer plants i.e. key species in first stages of succession subsequently replaced by angiosperms or filamentous algae especially as a result of eutrophication. In temporal water bodies charophytes are ephemeral or in other words meteoric in appearance. Several species mostly largest ones are perennial and may form communities which are the most stable in clear deep stratifying lakes [1].

The charophytes prefer alkaline water environment which forms on the carbonates that are very distributed in studied region. During last year's we find new, unstudied aquatic objects in which were identified charophyte algae [2]. They are apparently absent in single Israeli large lake (Lake Kinneret) for a long time as might be concluded from published data and our observations. Nearby regions, such as Turkey, also give us charophyte algae new localities that we studied in respect of species diversity and bio-indication of its environment $[3,4]$. Especially important to revealed the charophytes diversity in the Natural Reserves with saving diversity programs.

The aim of present study is to identify of charophyte and microscopic algal diversity that studied firstly in the Ein Afeq Natural Reserve pools, and to assess the pools environment by bio-indication methods on the base of revealed algae and water chemistry.

\section{Materials and Methods}

\subsection{Sampling and Laboratory Studies}

We collected fifteen living and fifteen fixed algological samples, twenty samples of charophytes and fifteen samples of water during six field trips from 2005 to 2015 in the Ein Afeq Natural Reserve pools (Figure 1).

Algological samples were collected by scratching and scooping, placed in $15 \mathrm{ml}$ plastic tubes, and partly fixed with $3 \%$ neutral formaldehyde solution, as well as partly not fixed and transported to the laboratory in the ice box.

We also studied eight dry samples of charophytes that were collected by Prof Yaakov Lipkin in February 1971 and April 1972 in the Ein Afeq area but without relation of individual waterbody. These samples were given to us for study under the grant of Israeli Taxonomical Initiative and are placed in the Tel Aviv University collection. 


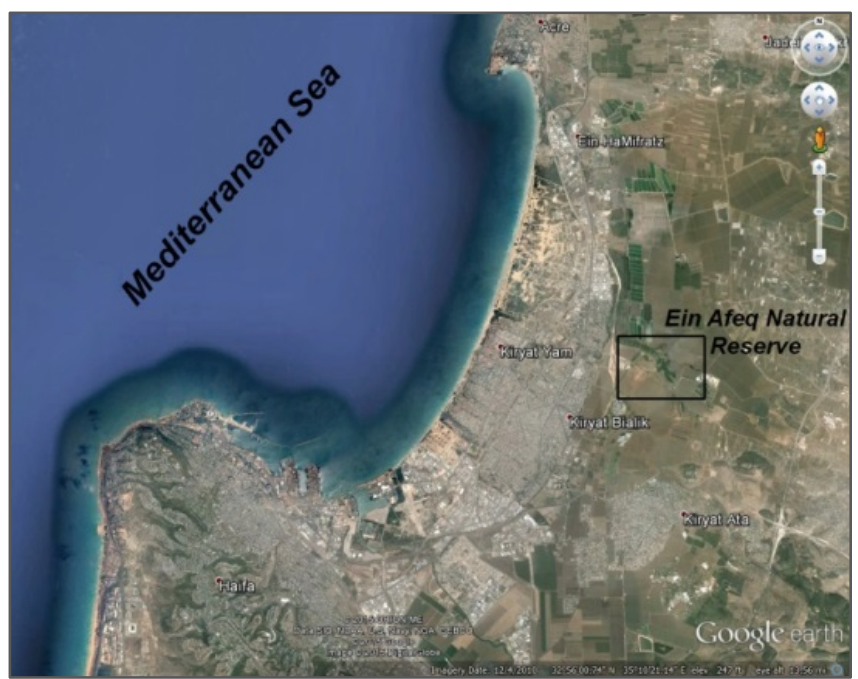

Figure 1. The Ein Afeq Natural Reserve in the Akko Plain of Northern Israel, marked with black rectangle

Charophytes were treated with $2-3 \% \mathrm{HCl}$ to remove calcium carbonate. After washing several times with distilled water the material was studied with Nikon stereomicroscope with distilled water the material was air-dried on cover glasses and mounted in Naphrax ${ }^{\circledR}$. The structure elements were observed with a Carl Zeiss Stereo Discovery V12 stereomicroscope equipped with an AxioCam MRs-5 digital camera and Axiovision 4.8 software, and DinoLight camera, the diatoms were observed with Nikon Eclipse Ci and SWIFT light microscopes (LM) and photographed with Leica $520 \mathrm{DC}$ in the Institute of Evolution, University of Haifa, and the Central Siberian Botanical Garden with help of international handbooks $[5,6]$. Charophyte and microscopic algae abundance were assessed as abundance scores according 6-score scale [7].

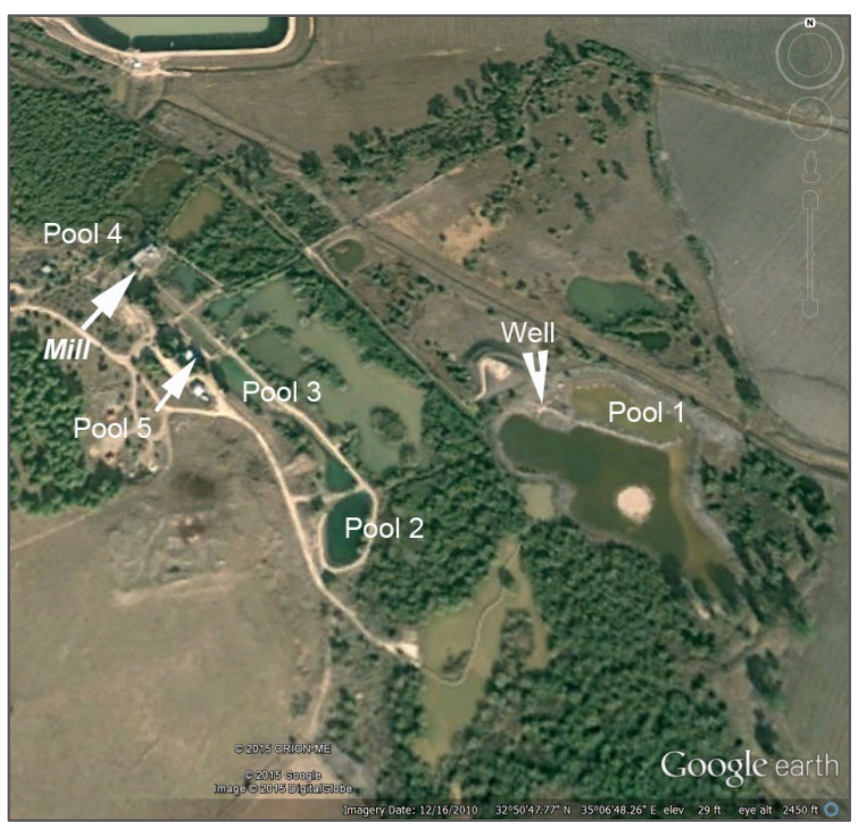

Figure 2. The Ein Afeq Natural Reserve, Pools with charophytes are numbered, central antique building of ancient mill marked with white arrow, the water Well pointed by white arrowhead
Algae and cyanobacteria were studied with the SWIFT and OLYMPUS dissecting microscopes under magnifications $740 x-1850 x$ from three repetitions of each sample and were photographed with a DC (OMAX A35100U). The diatoms were prepared by the peroxide technique [8] modified for glass slides [9] and were placed in the Naphrax ${ }^{\circledR}$ resin from two repetitions of each sample.

Temperature, Electrical conductivity (EC), Acidity (pH), and TDS were measured with HANNA HI 9813-0. The concentration of $\mathrm{N}^{-\mathrm{NO}_{3}}$ was measured with HANNA HI 93728.

Index saprobity s was calculated according to [10]. Index of aquatic ecosystem sustainable was calculated according to $[7,11]$ as $(1)$ :

$$
\text { WESI }=\text { Rank S / Rank N-NO } .
$$

Where: Rank S - rank of water quality on the Sladeček's indices of saprobity; Rank N-NO3 - rank of water quality on the nitric-nitrogen concentration (Table 1).

If WESI is equal to or larger than 1, the photosynthetic level is positively correlated with the level of nitrate concentration. If the WESI is less than 1, the photosynthesis is suppressed presumably according to toxic disturbance [7].

\subsection{Description of the Study Site}

The Ein Afeq Nature Reserve, on the outskirts of Kiryat Bialik, Northern Israel, is the last vestige of the Nahal Na aman swamps, which once extended all the way to the Acre valley (Figure 1).

The Ein Afeq Spring is in the nature reserve. A wooden path over the swamp passes near typical riverbank flora, such as tamarisk trees, blackberry hedges, reeds, and bulrushes. Plants growing in the water include duckweed and pond weeds [12]. When the water level rises in the winter, birds flock to the reserve: pelicans, cranes, pygmy cormorants, gray herons, moorhens, European coots, and black-winged stilts, to name just a few. In the winter and spring, the reserve is carpeted with flowers. A fine spot for admiring the blossoms is Tel Afeq, situated on a low sandstone hill on the edge of the reserve. On the northern slope of Tel Afeq is a two-story fortified building from the Crusader period [12].

System of natural and artificial pools is placed in the reserve territory (Figures 2-9) on altitude about $8 \mathrm{~m}$ above sea level with coordinates $32^{\circ} 50^{\prime} \mathrm{N}, 35^{\circ} 06^{\prime}$ E (Table 1). They are small, about 3-120 $\mathrm{m}$ in diameter and up to one $\mathrm{m}$ deep, filled by natural ground waters year-round, and used for education and recreation. Water source of the Na'aman River start from the Pool 1 and Well from the right side and follow to Pools 2 and 3 from the left side. The pools 4 and 5 are newly artificial. Each pool in the reserve is under management in purpose to save diversity of plants and animals. 


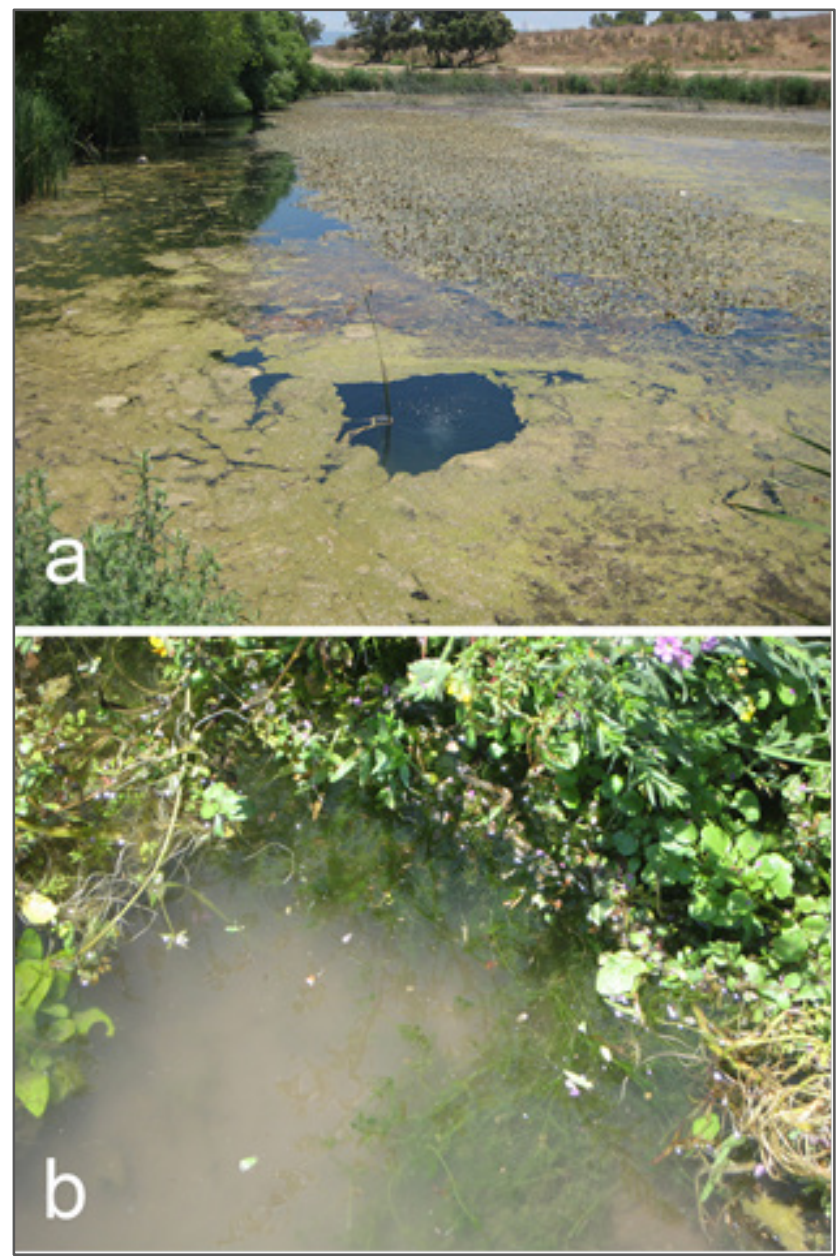

Figure 3. Pool 2: a - water pipe bubbles can be seen in the central part, July 2011; b - Chara vulgaris L. population near the pool bank in July 2011.
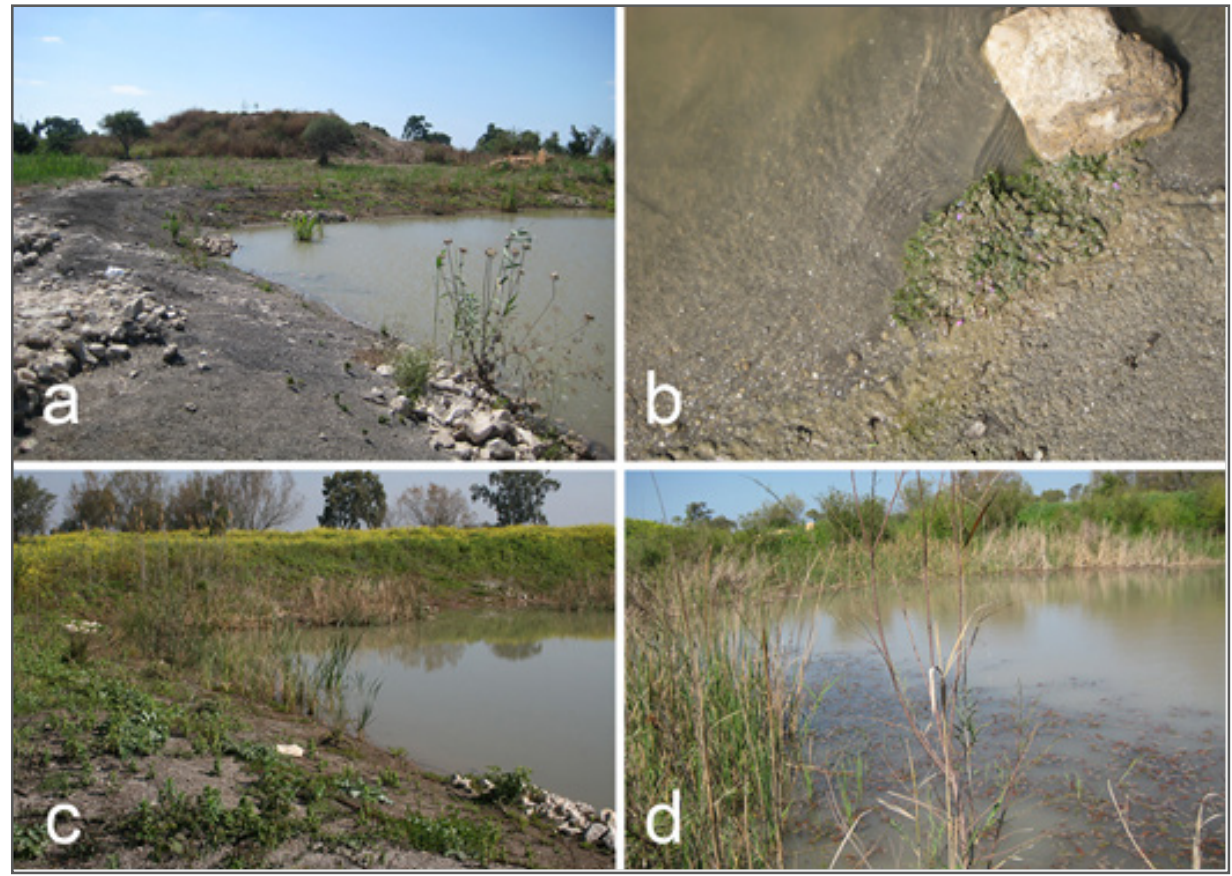

Figure 4. Pool 1 development from the same point of view: a - July 2011, c - March 2012, d - March 2015; b - Chara vulgaris initial population in July 2011 


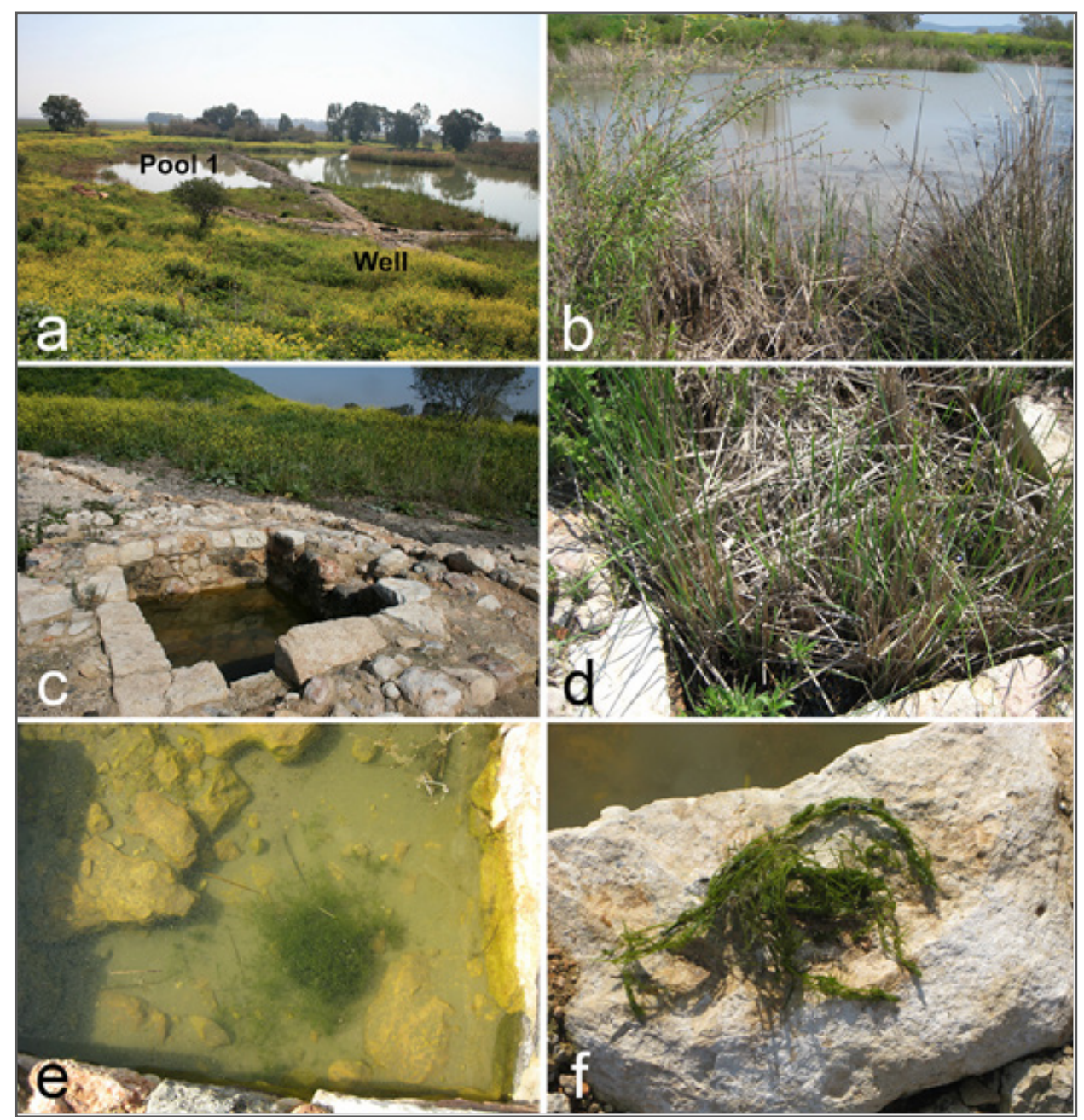

Figure 5. Pool 1 and Well development: a - March 2012 with water and nuded banks; b - Pool 1 in March 2015 with water and plants on the banks; $\mathrm{c}-$ Well in March 2012 with water and charophytes; d-Well in March 2015 without Chara and water; e, f-Chara vulgaris in Well, March 2012.

Table 1. Averaged chemical and biological variables of the Ein Afeq pools with charophytes in 2011-2015

\begin{tabular}{|c|c|c|c|c|c|c|c|c|c|c|c|c|}
\hline Pool & North & East & Season & Year & $\begin{array}{l}\text { Conductivity, } \\
\mathrm{mS} \mathrm{cm}^{-1}\end{array}$ & $\begin{array}{l}\mathrm{N}^{\mathrm{N} O} \mathrm{~N}_{3}, \\
\mathrm{mg} \mathrm{l}^{-1}\end{array}$ & $\mathrm{pH}$ & $\begin{array}{l}\text { TDS, } \\
\mathrm{mg} \mathrm{l}^{-1}\end{array}$ & $\begin{array}{l}\mathrm{T}, \\
{ }^{\circ} \mathrm{C}\end{array}$ & $\begin{array}{l}\text { No. of } \\
\text { Species }\end{array}$ & $\begin{array}{c}\text { Index } \\
\mathrm{S}\end{array}$ & $\begin{array}{l}\text { Index } \\
\text { WESI }\end{array}$ \\
\hline 1 & $32^{\circ} 50^{\prime} 48.0^{\prime \prime}$ & $35^{\circ} 06^{\prime} 58.0^{\prime \prime}$ & Summer & 2011 & 3.09 & 0.60 & 8.0 & - & 33.0 & 25 & 1.74 & 1.0 \\
\hline Well & $32^{\circ} 50^{\prime} 48.0^{\prime \prime}$ & $35^{\circ} 06^{\prime} 56.0^{\prime \prime}$ & Winter & 2012 & 2.76 & 0.70 & 7.1 & 1733 & 15.7 & 10 & 1.84 & 1.0 \\
\hline 2 & $32^{\circ} 50^{\prime} 76.9^{\prime \prime}$ & $35^{\circ} 06^{\prime} 83.8^{\prime \prime}$ & Summer & 2011 & 2.44 & 7.40 & 6.9 & 1814 & 25.6 & 26 & 1.71 & 0.4 \\
\hline 3 & $32^{\circ} 50^{\prime} 84.4^{\prime \prime}$ & $35^{\circ} 06^{\prime} 76.7^{\prime}$ & Summer & 2011 & 2.54 & 2.70 & 7.4 & 1902 & 28.5 & 5 & 1.53 & 0.5 \\
\hline 4 & $32^{\circ} 50^{\prime} 53.0^{\prime \prime}$ & $35^{\circ} 06^{\prime} 43.0^{\prime \prime}$ & Winter & $\begin{array}{l}2012- \\
2015\end{array}$ & 0.39 & 0.87 & 8.5 & 282.3 & 16.8 & 37 & 1.58 & 1.0 \\
\hline 5 & $32^{\circ} 50^{\prime} 50.2^{\prime \prime}$ & $35^{\circ} 06^{\prime} 44.5^{\prime}$ & Winter & 2015 & 1.32 & 1.00 & 9.4 & 955.6 & 20.0 & 14 & 1.43 & 0.8 \\
\hline
\end{tabular}


Table 2. Algal diversity with abundance scores and species ecological preferences (according to [7,13]) in the Ein Afeq Natural Reserve pools in 2005-2015

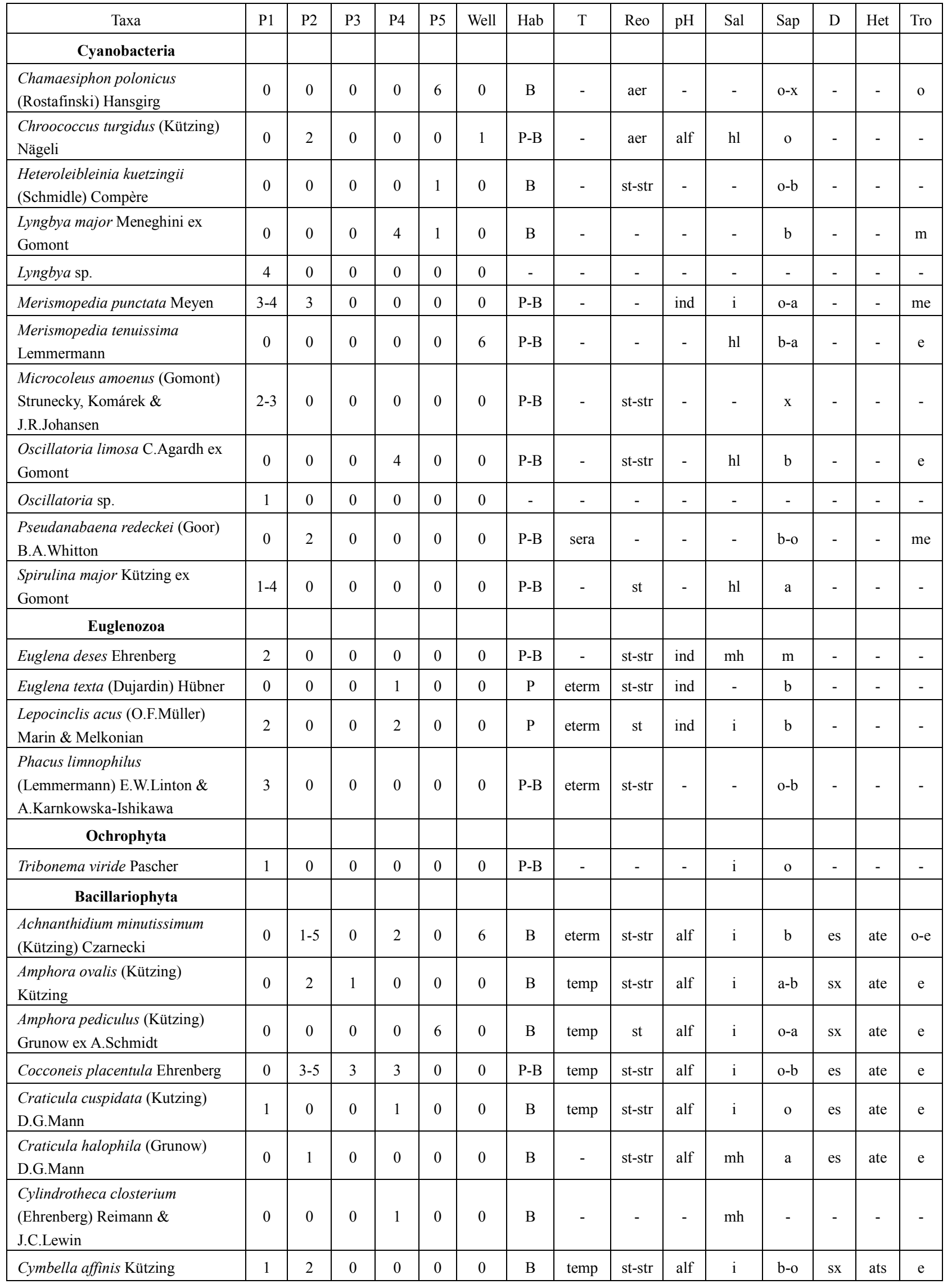




\begin{tabular}{|c|c|c|c|c|c|c|c|c|c|c|c|c|c|c|c|}
\hline Cymbella turgidula Grunow & 3 & 3 & 0 & 1 & 0 & 0 & B & - & st-str & ind & - & - & es & - & - \\
\hline $\begin{array}{l}\text { Epithemia adnata (Kützing) } \\
\text { Brébisson }\end{array}$ & 0 & 0 & 0 & 4 & 6 & 0 & $\mathrm{~B}$ & temp & st & alb & $\mathrm{i}$ & $\mathrm{b}-\mathrm{a}$ & sx & ats & me \\
\hline $\begin{array}{l}\text { Fragilaria radians (Kützing) } \\
\text { D.M.Williams \& Round }\end{array}$ & 0 & 0 & 0 & 0 & 0 & 2 & B & - & - & alf & $\mathrm{i}$ & o & sx & - & - \\
\hline Gomphonema gracile Ehrenberg & 0 & 0 & 0 & 0 & 3 & 0 & P-B & temp & st & alf & $\mathrm{i}$ & $b-o$ & es & ats & $\mathrm{m}$ \\
\hline $\begin{array}{l}\text { Gomphonema longiceps } \\
\text { Ehrenberg }\end{array}$ & 0 & 2 & 0 & 0 & 0 & 0 & B & - & str & ind & $\mathrm{i}$ & o-b & es & - & - \\
\hline $\begin{array}{l}\text { Gomphonema parvulum (Kützing) } \\
\text { Kützing }\end{array}$ & 1 & 1 & 0 & 1 & 1 & 1 & B & temp & str & ind & i & $\mathrm{x}$ & es & hne & $\mathrm{e}$ \\
\hline $\begin{array}{l}\text { Gomphonemopsis obscura } \\
\text { (Krasske) Lange-Bertalot }\end{array}$ & 0 & 0 & 1 & 0 & 0 & 0 & B & - & - & - & $\mathrm{hl}$ & - & - & - & - \\
\hline $\begin{array}{l}\text { Grunowia sinuata (Thwaites) } \\
\text { Rabenhorst }\end{array}$ & 0 & 6 & 0 & 0 & 0 & 0 & B & - & str & ind & i & $b-a$ & - & ats & $\mathrm{m}$ \\
\hline $\begin{array}{l}\text { Gyrosigma acuminatum (Kützing) } \\
\text { Rabenhorst }\end{array}$ & 4 & 0 & 0 & 3 & 0 & 0 & B & cool & st-str & alf & $\mathrm{i}$ & $\mathrm{o}-\mathrm{X}$ & - & ate & $\mathrm{e}$ \\
\hline $\begin{array}{l}\text { Halamphora holsatica (Hustedt) } \\
\text { Levkov }\end{array}$ & 2 & 0 & 0 & 0 & 0 & 0 & $\mathrm{P}$ & - & st-str & - & hl & - & - & - & - \\
\hline $\begin{array}{l}\text { Haslea spicula (Hickie) } \\
\text { L.Bukhtiyarova }\end{array}$ & 2 & 0 & 0 & 0 & 0 & 3 & P-B & - & - & - & $\mathrm{mh}$ & - & - & - & - \\
\hline Navicula cincta (Ehrenberg) Ralfs & 0 & 0 & 0 & 1 & 0 & 0 & $\mathrm{~B}$ & warm & st-str & alf & hl & $\mathrm{x}-\mathrm{O}$ & es & ate & $\mathrm{e}$ \\
\hline Navicula exigua Gregory & 3 & 4 & 0 & $1-3$ & 0 & 2 & B & - & str & alf & $\mathrm{i}$ & $\mathrm{x}-\mathrm{O}$ & es & ats & $\mathrm{e}$ \\
\hline $\begin{array}{l}\text { Navicula recens (Lange-Bertalot) } \\
\text { Lange-Bertalot }\end{array}$ & 2 & 0 & 0 & 1 & 0 & 0 & P-B & - & - & alf & $\mathrm{i}$ & $\mathrm{o}-\mathrm{b}$ & es & - & $\mathrm{e}$ \\
\hline Navicula rhynchocephala Kützing & 2 & 2 & 0 & 0 & 0 & 0 & B & - & - & alf & hl,i & $\mathrm{b}$ & - & ate & o-e \\
\hline Nitzschia commutata Grunow & 0 & 0 & 0 & 1 & 1 & 0 & B & - & - & - & $\mathrm{mh}$ & - & - & - & - \\
\hline $\begin{array}{l}\text { Nitzschia fonticola (Grunow) } \\
\text { Grunow }\end{array}$ & $1-6$ & 3 & 1 & 2 & 0 & 0 & B & - & st-str & alf & oh & $\mathrm{o}-\mathrm{b}$ & - & ate & me \\
\hline Nitzschia gracilis Hantzsch & 0 & 0 & 0 & 2 & 0 & 0 & P-B & temp & st-str & ind & $\mathrm{i}$ & $0-\mathrm{x}$ & $\mathrm{sp}$ & - & $\mathrm{m}$ \\
\hline $\begin{array}{l}\text { Nitzschia palea (Kützing) } \\
\text { W.Smith }\end{array}$ & 2 & 2 & 0 & 2 & 0 & 0 & P-B & temp & - & ind & $\mathrm{i}$ & $\mathrm{o}-\mathrm{x}$ & $\mathrm{sp}$ & hce & he \\
\hline Nitzschia solita Hustedt & 1 & 0 & 0 & 1 & 0 & 2 & B & - & st & alf & $\mathrm{mh}$ & $a-b$ & es & - & $\mathrm{e}$ \\
\hline Nitzschia tryblionella Hantzsch & 0 & 0 & 0 & 2 & 0 & 1 & B & - & st-str & alf & $\mathrm{hl}, \mathrm{mh}$ & o & - & ate & $\mathrm{e}$ \\
\hline $\begin{array}{l}\text { Nitzschia vermicularis (Kützing) } \\
\text { Hantzsch }\end{array}$ & 0 & 0 & 0 & 2 & 0 & 0 & B & - & str & alf & $\mathrm{i}$ & o & - & - & o-e \\
\hline $\begin{array}{l}\text { Rhopalodia gibba (Ehrenberg) } \\
\text { Otto Müller }\end{array}$ & 0 & 0 & 0 & 1 & 0 & 0 & B & temp & - & alb & $\mathrm{i}$ & $\mathrm{x}-\mathrm{O}$ & es & - & - \\
\hline $\begin{array}{l}\text { Sellaphora pupula (Kützing) } \\
\text { Mereschkovsky }\end{array}$ & 1 & 0 & 0 & 0 & 0 & 0 & B & eterm & st & ind & hl & $\mathrm{x}-\mathrm{O}$ & sx & ate & me \\
\hline $\begin{array}{l}\text { Stephanodiscus hantzschii } \\
\text { Grunow }\end{array}$ & 0 & 2 & 0 & 0 & 0 & 0 & $\mathrm{P}$ & temp & st & alf & $\mathrm{i}$ & $a-b$ & es & hne & he \\
\hline Surirella ovalis Brébisson & 0 & 1 & 0 & 0 & 0 & 0 & $\mathrm{~B}$ & - & st-str & ind & $\mathrm{i}$ & $\mathrm{o}-\mathrm{a}$ & es & - & - \\
\hline $\begin{array}{l}\text { Tropidoneis gibberula (Grunow) } \\
\text { Cleve }\end{array}$ & 0 & 0 & 0 & 4 & 0 & 0 & B & - & - & - & - & - & - & - & - \\
\hline Tryblionella angustata W.Smith & 0 & 0 & 0 & 1 & 0 & 0 & $\mathrm{P}$ & - & st & alf & $\mathrm{i}$ & $x-b$ & sx & ats & $\mathrm{m}$ \\
\hline $\begin{array}{l}\text { Tryblionella hungarica (Grunow) } \\
\text { Frenguelli }\end{array}$ & 0 & 0 & 0 & 1 & 0 & 0 & P-B & - & - & alf & $\mathrm{mh}$ & $a-b$ & $\mathrm{sp}$ & ate & $\mathrm{e}$ \\
\hline $\begin{array}{l}\text { Tryblionella kuetzingii } \\
\text { Álvarez-Blanco \& S.Blanco } \\
\end{array}$ & 0 & 1 & 0 & 0 & 0 & 0 & B & - & st-str & alf & $\mathrm{mh}$ & $\mathrm{b}$ & es & ate & e \\
\hline $\begin{array}{l}\text { Ulnaria danica (Kützing) } \\
\text { Compère \& Bukhtiyarova }\end{array}$ & 0 & 1 & 0 & 0 & 0 & 0 & P-B & temp & - & alf & $\mathrm{i}$ & $\mathrm{x}-\mathrm{b}$ & es & - & - \\
\hline Ulnaria ulna (Nitzsch) P.Compère & 0 & $1-4$ & 0 & 1 & 0 & 0 & B & temp & st-str & alf & $\mathrm{i}$ & $b-o$ & es & ate & o-e \\
\hline
\end{tabular}




\begin{tabular}{|c|c|c|c|c|c|c|c|c|c|c|c|c|c|c|c|}
\hline Chlorophyta & & & & & & & & & & & & & & & \\
\hline $\begin{array}{l}\text { Cladophora glomerata (Linnaeus) } \\
\text { Kützing }\end{array}$ & 0 & 0 & 0 & 6 & 6 & 0 & P-B & - & st-str & alf & $\mathrm{i}$ & $b-o$ & - & - & - \\
\hline $\begin{array}{l}\text { Desmodesmus brasiliensis } \\
\text { (Bohlin) E.Hegewald }\end{array}$ & 0 & 0 & 0 & 2 & 0 & 0 & P-B & - & st-str & - & - & $\mathrm{b}$ & - & - & - \\
\hline Eudorina elegans Ehrenberg & 0 & 0 & 0 & 1 & 0 & 0 & $\mathrm{P}$ & - & st-str & - & $\mathrm{i}$ & $\mathrm{b}$ & - & - & - \\
\hline Oedogonium sp. ster. & 1 & 0 & 0 & $3-6$ & 5 & 0 & - & - & - & - & - & - & - & - & - \\
\hline $\begin{array}{l}\text { Scenedesmus apiculatus var. } \\
\text { indicus (Hortobágyi) Hortobágyi }\end{array}$ & 0 & 3 & 0 & 0 & 0 & 0 & P-B & - & st & - & - & - & - & - & - \\
\hline $\begin{array}{l}\text { Scenedesmus obliquus (Turpin) } \\
\text { Kützing }\end{array}$ & 0 & 4 & 0 & 0 & 0 & 0 & P-B & - & st-str & - & $\mathrm{i}$ & $\mathrm{b}$ & - & - & - \\
\hline \multicolumn{16}{|l|}{ Charophyta } \\
\hline $\begin{array}{l}\text { Chara connivens P.Salzmann ex } \\
\text { A.Braun }\end{array}$ & 0 & 0 & 0 & 4 & 3 & 0 & B & - & - & - & - & - & - & - & - \\
\hline Chara vulgaris Linnaeus & 1 & 2 & 4 & $2-6$ & 0 & 2 & B & - & st-str & - & - & o & - & - & - \\
\hline $\begin{array}{l}\text { Closterium acerosum Ehrenberg } \\
\text { ex Ralfs }\end{array}$ & 0 & 0 & 0 & 3 & 0 & 0 & P-B & - & st-str & ind & $\mathrm{i}$ & $a-b$ & - & - & me \\
\hline Coleochaete pulvinata A.Braun & 0 & 0 & 0 & 0 & 6 & 0 & Ep & - & st & - & - & o & - & - & - \\
\hline $\begin{array}{l}\text { Cosmarium punctulatum } \\
\text { Brébisson }\end{array}$ & 0 & 0 & 0 & 1 & 1 & 0 & P-B & - & - & acf & $\mathrm{hb}$ & o & - & - & - \\
\hline Mougeotia sp. ster. & 0 & 4 & 0 & 0 & 0 & 0 & $\mathrm{~B}$ & - & - & - & - & o & - & - & - \\
\hline Spirogyra sp. ster. & 0 & 2 & 0 & $1-4$ & 0 & 0 & - & - & - & - & - & - & - & - & - \\
\hline Zygnema sp. ster. & 0 & 0 & 0 & 1 & 0 & 0 & $\mathrm{~B}$ & - & - & - & - & $x-b$ & - & - & - \\
\hline
\end{tabular}

Note: Ecological types (Hab): Ep, epiphyte; B, benthic; P-B, planktonic-benthic; P, planktonic. Temperature (T): cool, cool water inhabitant; temp, temperate waters inhabitant; eterm, eurytermic; warm, warm waters inhabitant; sera, $\mathrm{H}_{2} \mathrm{~S}$ indicator. Streaming and Oxygenation (Reo): aer, aerophile; str, streaming waters inhabitant; st-str, low streaming waters inhabitant; st, standing water inhabitant. Acidity (pH): acf, acidophil; ind, indifferent; alf, alkaliphil; alb, alkalibiont. Halobity (Sal): hb, halophobe; i, oligohalobious-indifferent; hl, oligohalobious-halophilous; mh, mesohalobe. Saprobity (D): sp, saprophil; es, eurysaprob; sx, saproxen. Saprobity (Sap): o, oligosaprob; o-a, oligo-alpha-mesosaprob; o-x, oligo-xenosaprob; x-o, xeno-oligosarob; $\mathrm{x}$-b, xeno-beta-mesosaprob; $\mathrm{x}$, xenosaprob; o-b, oligo-beta-mesosaprob; b-o, beta-oligosaprob; b, beta-mesosaprob; b-a, beta-alpha-mesosaprob; a-b, alpha-beta-mesosaprob; a, alpha-mesosaprob; $m$, metasaprob. Nitrogen uptake metabolism (Aut-Het) [13]: ats, nitrogen-autotrophic taxa, tolerating very small concentrations of organically bound nitrogen; ate, nitrogen-autotrophic taxa, tolerating elevated concentrations of organically bound nitrogen; hne, facultatively nitrogen-heterotrophic taxa, needing periodically elevated concentrations of organically bound nitrogen; hce, nitrogen-heterotrophic taxa, needing elevated concentrations of organically bound nitrogen. Trophic state (Tro) [13]: o, oligotrafentic; m, mesotraphentic; me, meso-eutraphentic; e, eutraphentic; he, hypereutraphentic; o-e, oligo- to eutraphentic (hypereutraphentic).

Climatic condition of the Ein Afeq area is warm and temperate with more rainfall in the winter than in the summer and mean annual rainfall about $531 \mathrm{~mm}$. The driest month is June, with $0 \mathrm{~mm}$ of rain. With an average of 141 $\mathrm{mm}$, the most precipitation falls in January. The temperature here averages $20.4{ }^{\circ} \mathrm{C}$. August is the warmest month of the year with averages $27.3^{\circ} \mathrm{C}$. January has the lowest average temperature of the year about $13.1{ }^{\circ} \mathrm{C}$ [14]. Therefore, Afeq environment is very favorable for the development of photosynthetic plants and charophyte algae which are truly photosynthetic organisms.

\section{Results and Discussion}

\subsection{Chemical Composition of the Pools Water}

Chemical variables were measured in two seasons: summer and winter. Table 1 shows that environment variables are fluctuated over pools and seasons. Water conductivity and TDS have wide range in two newest pools 1 and 4, whereas old stabile pools 2 and 3 are in the same range. Pool 5 represent small artificial betony construction filled by natural water and is clearer. Water $\mathrm{pH}$ is higher in the newest pools. Remarkable that Pool 2, deepest, has average in neutral water. As can be seen in Figure 5a, the water comes to the Pool 2 not only from the bottom but also from artificial source. Nitrogen concentration varied in natural range. Water temperature fluctuated in climatic norm with highest $\left(33^{\circ} \mathrm{C}\right)$ in the shallow Pool 1 in summer. Therefore, the pools water can be characterized as fresh, low alkaline, moderate temperature, and low polluted $[7,11]$. Index of saprobity $\mathrm{S}$ is fluctuated between 1.43 in the newest Pool 5 and 1.83 in the Well, and reflects Class II to III of Water Quality.

\subsection{Diversity and Ecology of Algae}

We revealed seventy one species of algae (Table 2) diversity of which is rather fluctuated between pools. Diatoms prevail in oldest but replaced by charophytes, greens and cyanobacteria in newest pools 1,4 , and 5 .

Two macrophyte algae Chara connivens (Figures 10-12) and C. vulgaris (Figure 13) were found in different pools. Structural elements and thallus habitat for both species confirm that our samples are in the typical diagnosis frames. 
It is also widely distributed species in the Mediterranean countries and some climatic similar regions [15] (algaebase.org). Chara vulgaris is simply separated from the other members of the genus Chara as we revealed by AFLP analysis [16]. It is two species that we found as distributed in Israel in historical and present time [2]. Chara vulgaris is a common and found most frequently in comparison with other species.
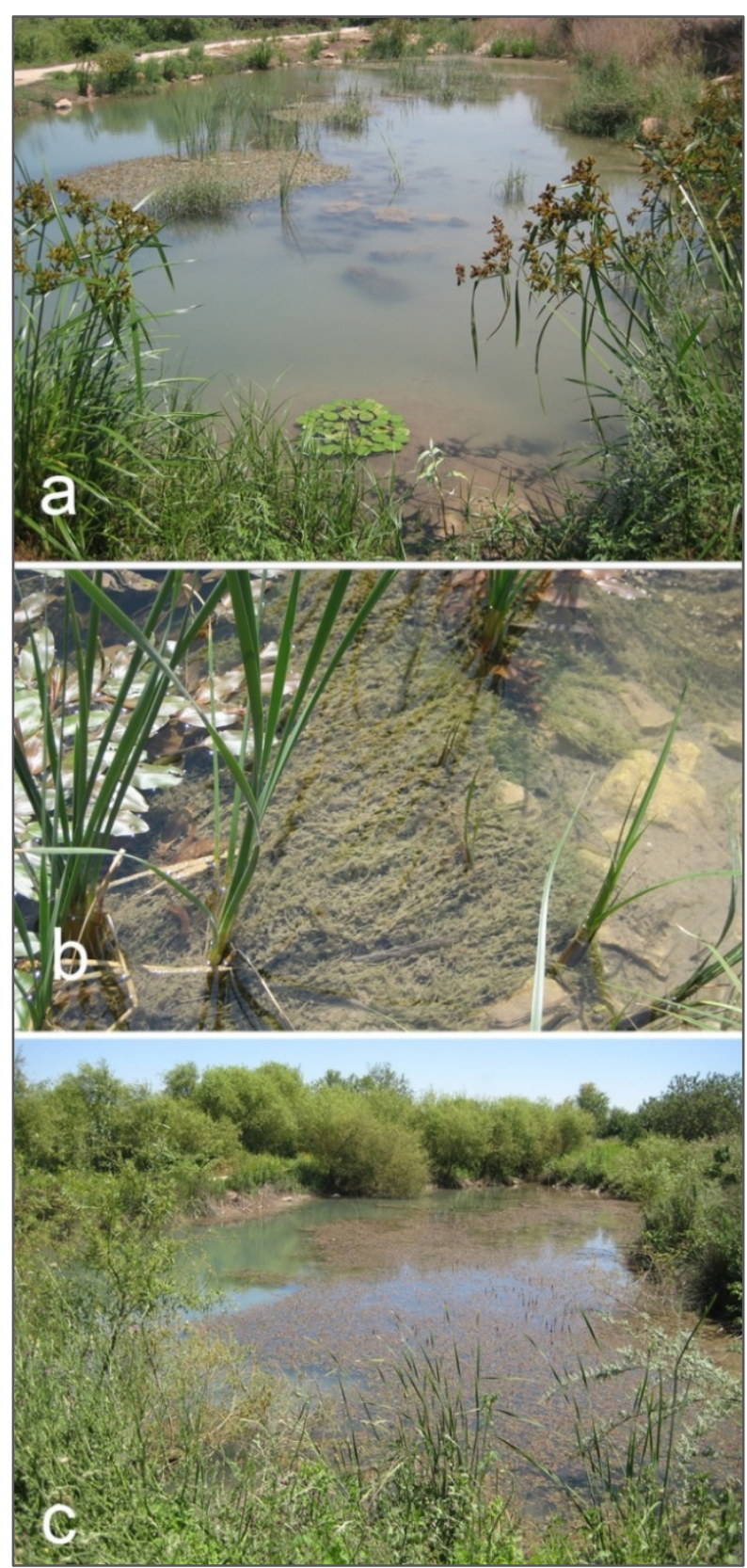

Figure 6. Pool 3: a - low covered by aquatic plants in July 2011; b Chara vulgaris, in water input to the Pool 3, July 2011; c - Pool 3 covered by aquatic plants and without charophytes, March 2012.

Chara vulgaris was found in all studied pools except newest artificial Pool 5, but C. connivens was grow in pools 4 and 5 only. During ten year study of the Ein Afeq pools, we explore successional changes over the pools diversity. So, in 2005 the charophytes were absent. Chara vulgaris was found in oldest Pool 2 in 2011 (Figure 3b) and Pool 3 (Figure 6b). Just created Pool 1 in 2011 contains C. vulgaris (Figure 4e), as well as Well in 2012 (Figure 5e,f) but only once during study period. Successional picture shows community in Pool 4 where in just created pool we found C. vulgaris in March 2012 (Figure 7b) that accompanied by C. connivens (Figure 7c) in initial stage and sterile. Later, in March and April 2015 the role of species in community change vice versa (Figure $8 b, c)$.

Communities of $C$. connivens and C. vulgaris are pioneer communities mostly in ephemeral shallow or temporary water bodies, basic, rich in lime, sometimes sub-brackish, mesotrophic to slightly eutrophic for $C$. connivens and mesotrophic to eutrophic for C. vulgaris [17]. The last species is one of the most resistant to eutrophication among charophytes [6].
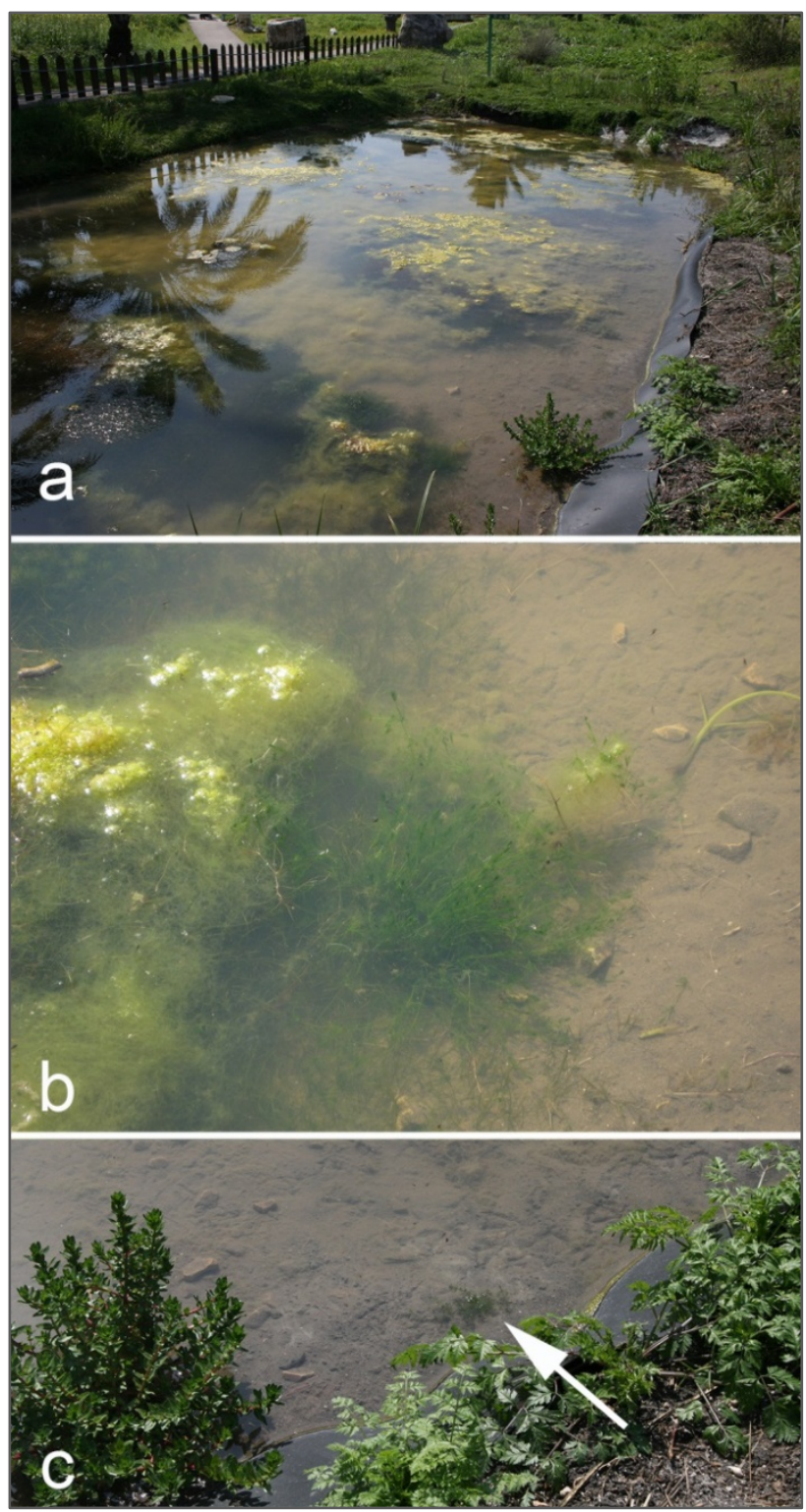

Figure 7. Pool 4: a - pool in initial stage in March 2012; b - Chara vulgaris massive grow with Spirogyra sp. ster., March 2012; c - initial thallus of $C$. cf. connivens Salzm. ex A. Braun ster. (white arrow), March 2012 . 


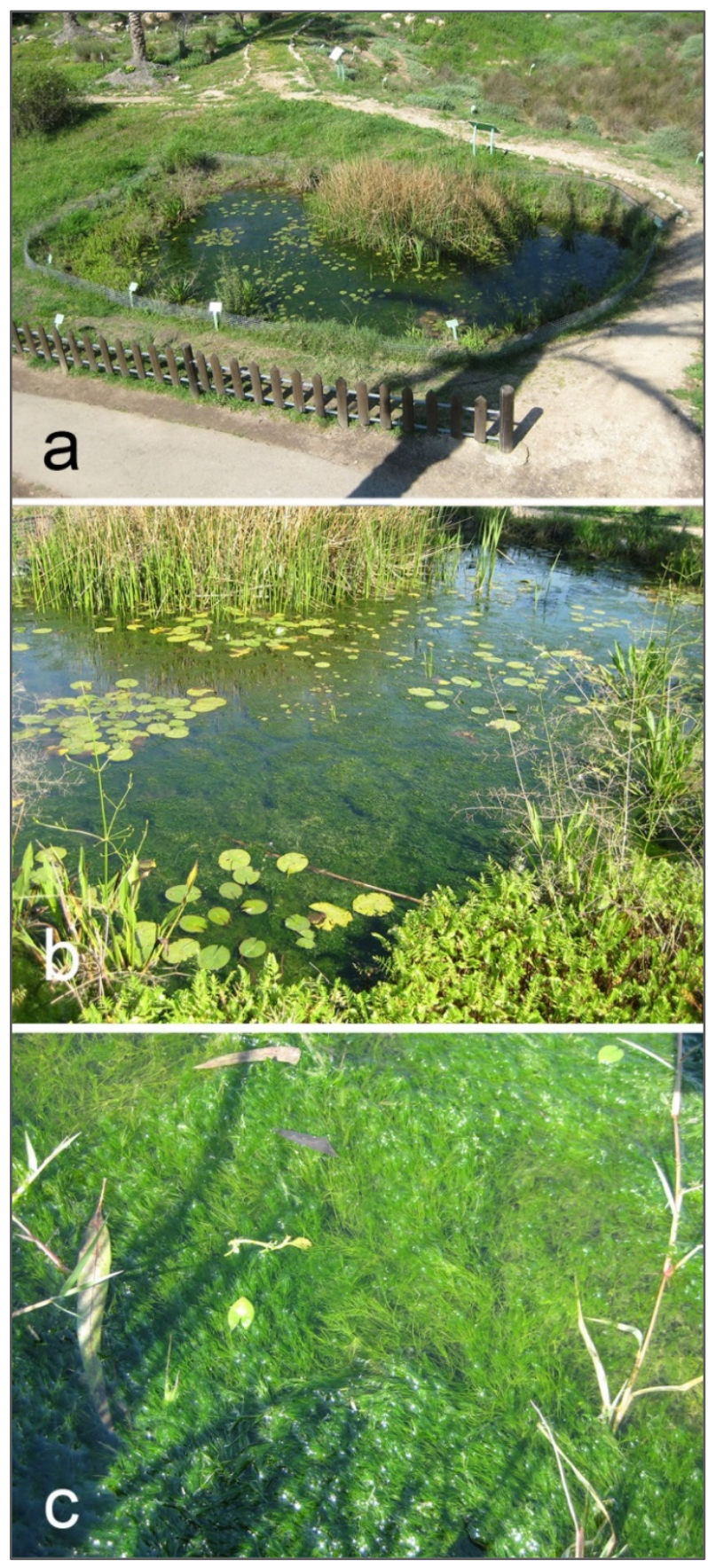

Figure 8. Pool 4: a - total view in 2015 with massive grows of charophytes and aquatic plants; b, c - Chara cf. connivens ster. massive grow, March 2015.

Community of each studied pool was different in species richness as well as in species contain. So, the richest communities were found in the newest Pool 4 with 14 species, and Pool 1 with 13 taxa. Deepest Pool 2 was with 12 taxa, and the betony new Pool 5 with 11. Algal communities in pools were reached by diatoms (Table 2). Pool 1 was dominated by Nitzschia fonticola, Pool 2 - by Achnanthidium minutissimum and Cocconeis placentula. Community in Pool 3 was mostly represented by Chara vulgaris. Pool 4 represents strongly domination of Chara connivens in its lather succession stage which was attached by mass of green filaments of Oedogonium sp. ster. In Pool 5 community was new, Chara connivens thalluses were attached by the same Oedogonium filaments with diatom Epithemia adnata, green Coleochaete pulvinata, and cyanoprokaryote Chamaesiphon masses especially in the oldest Chara individuals. Algal community in the Well was pure and represent by Chara vulgaris with attached diatom Achnanthidium minutissimum.

We explore succession of higher water plants in studied pools as not only progressive, but even aggressive. So, the Well evolved from pure and low watered object to full overgrow by plants and empty of water and charophyte community (Figure $5 \mathrm{c}, \mathrm{d}$ ). Pool 1 also has progress in the aquatic plants during 2011-2015 (Figure 4a,c,d; 5b). In pool 3 we can see the same tendency in the Figure 6a,c. The charophytes left Pool 2, that can be related with increasing of organic pollution from 2005 to 2015 as a result of recreation which confirmed by nitric-nitrogen increasing up to $7.4 \mathrm{mg}$ $1^{-1}$. Up to now we don't explore the advanced succession stages in the newest pools 4 and 5 , but revealed tendency in incursion of high plants in oldest pools can be endangered other algal communities because high plants replacing charophytes. It helps us to assume that charophytes can be used as indicators of succession stage in aquatic communities. More of them, Chara vulgaris represents the exponential succession stage whereas Chara connivens replace it in succession advances.
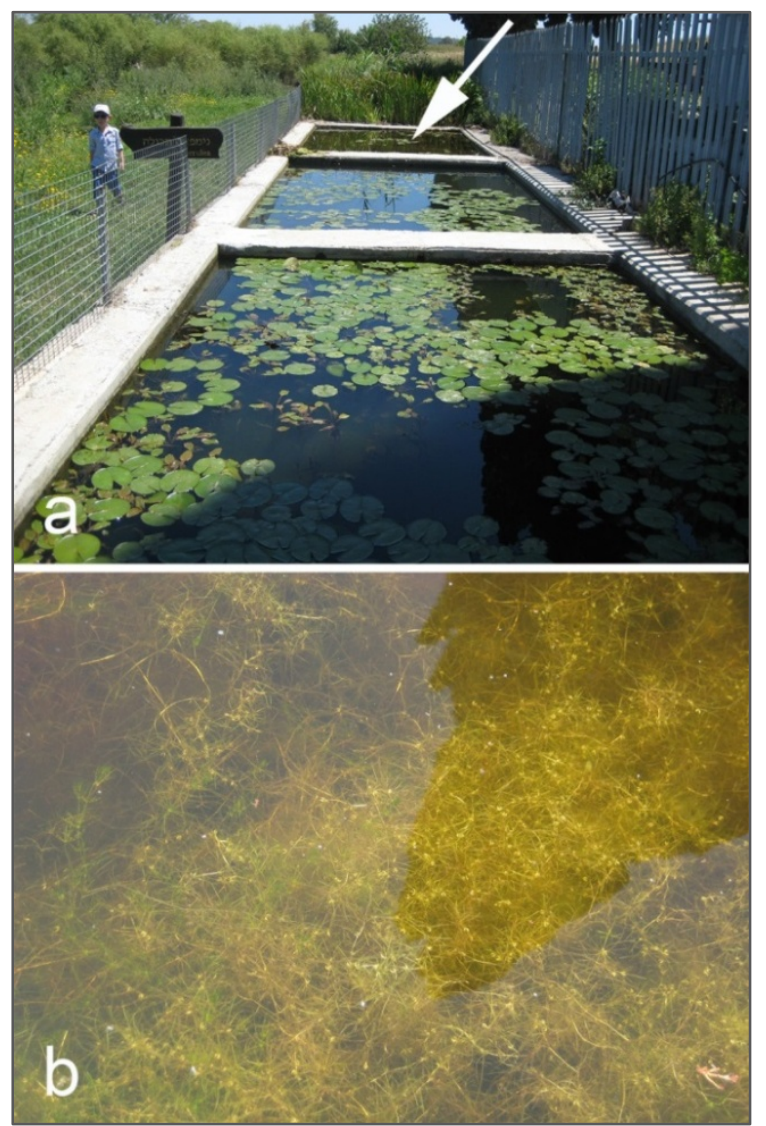

Figure 9. Pool 5: a - total view of betony cascade pools in 2015 with the last one as Pool 5, pointed by white arrow; b - Chara connivens grow, April 2015. 


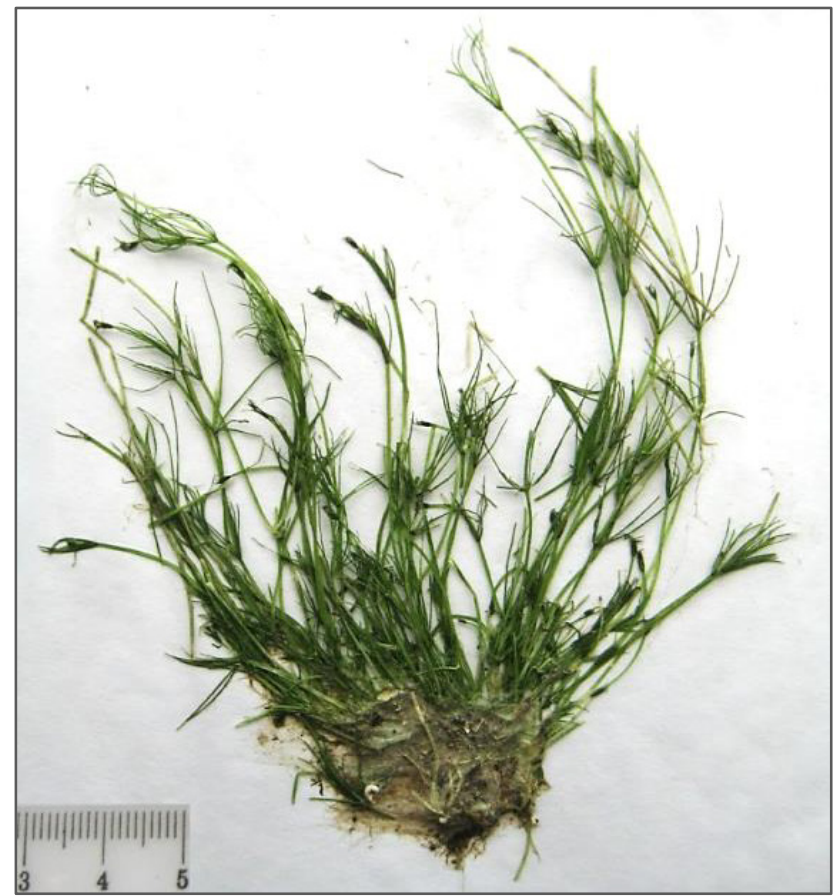

Figure 10. Chara cf. connivens ster. total view of thallus in Pool 4, March 2012.

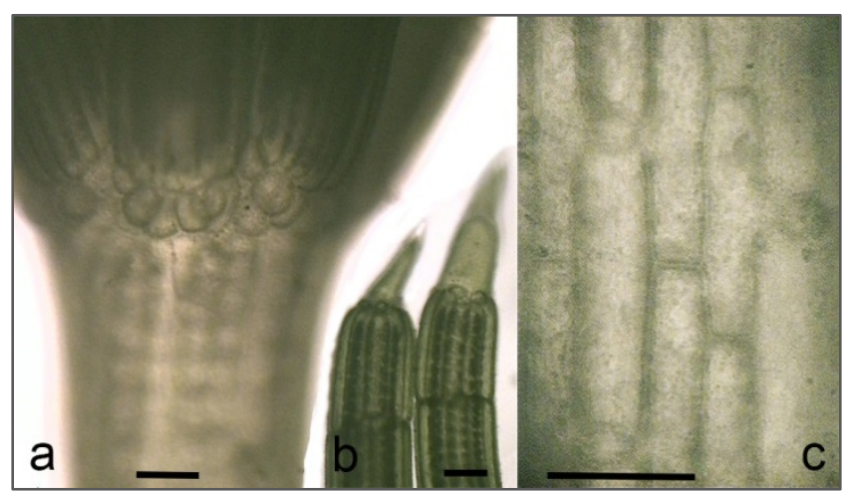

Figure 11. Chara cf. connivens ster. in Pool 4, March 2012: a - axis with stipulodes and base of whorl; b-branches end cells; $\mathrm{c}$ - axis with triplostichous axial cortex. Scale bars: $\mathrm{a}-100 \mathrm{um} ; \mathrm{b}-50 \mathrm{um} ; \mathrm{c}-100 \mathrm{um}$.

In this case it is remarkable that charophytes in the Ein Afeq pools can not only change its diversity over the time but also survive with helps of oospores in the pools sediments. We don't find yet other species of charophytes in the Ein Afeq nevertheless its pools and climatic conditions represent well environment for its surviving.

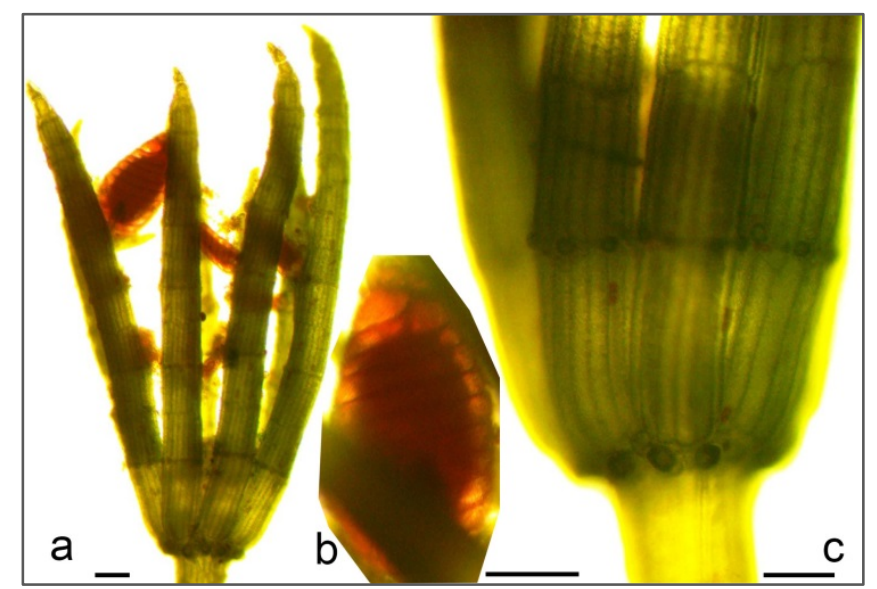

Figure 12. Chara connivens in Pool 5, April 2015: a - axis with whorl of branchlets and oogonia; $\mathrm{b}$ - oogonium; $\mathrm{c}$ - axis with stipulodes, base of whorl. Scale bars: 200 um. 
We are grateful to have access to the Tel Aviv University herbarium in the frame of Israeli Taxonomic Initiative Grant. Dr. Lipkin collection let us to assume that we don't exhaustive the charophytes list in this protected area and in future can find also Chara vulgaris var. longibracteata (Kütz.) J. Gr. et B. Webst. (Figure 14).

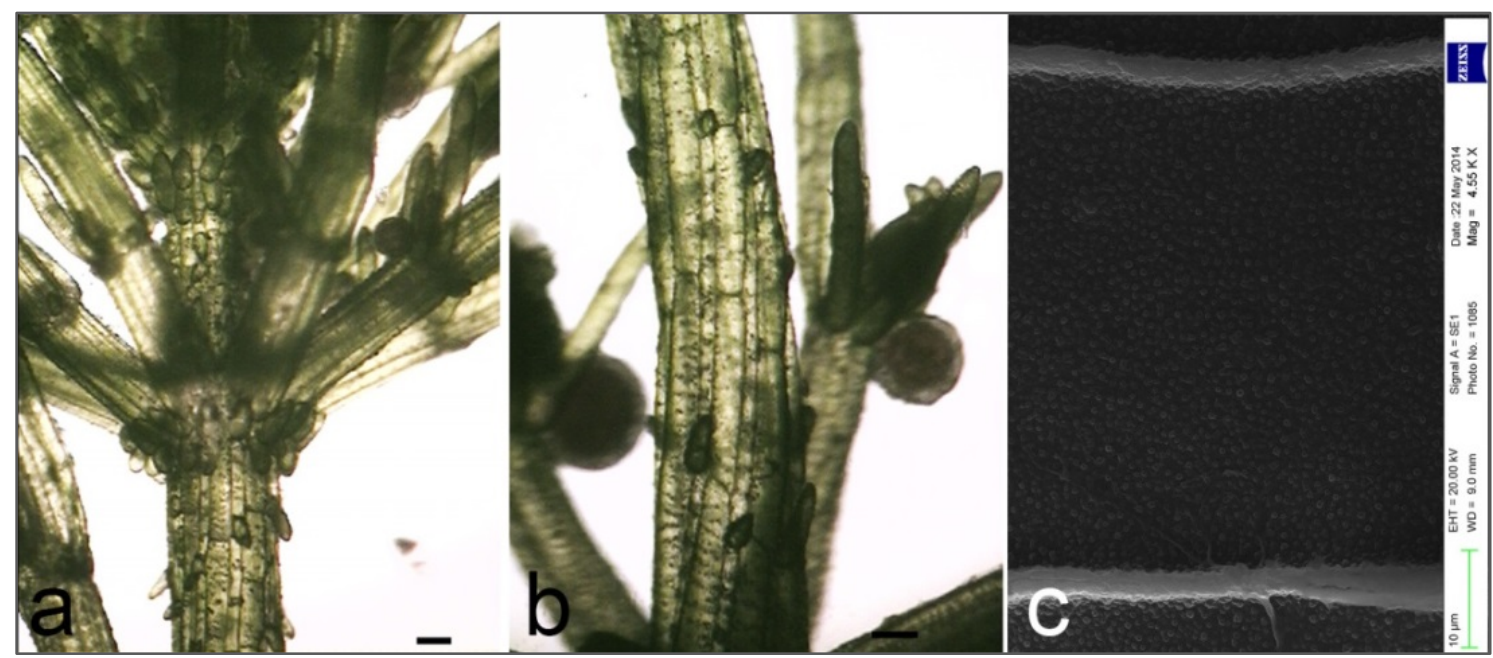

Figure 13. Chara vulgaris in Pool 4, March 2012: a - axis with stipulodes and base of whorl; b - axis with axial cortex and germination cells; $\mathrm{c}-$ oospore wall structure, SEM. Scale bars: $a, b-100$ um.

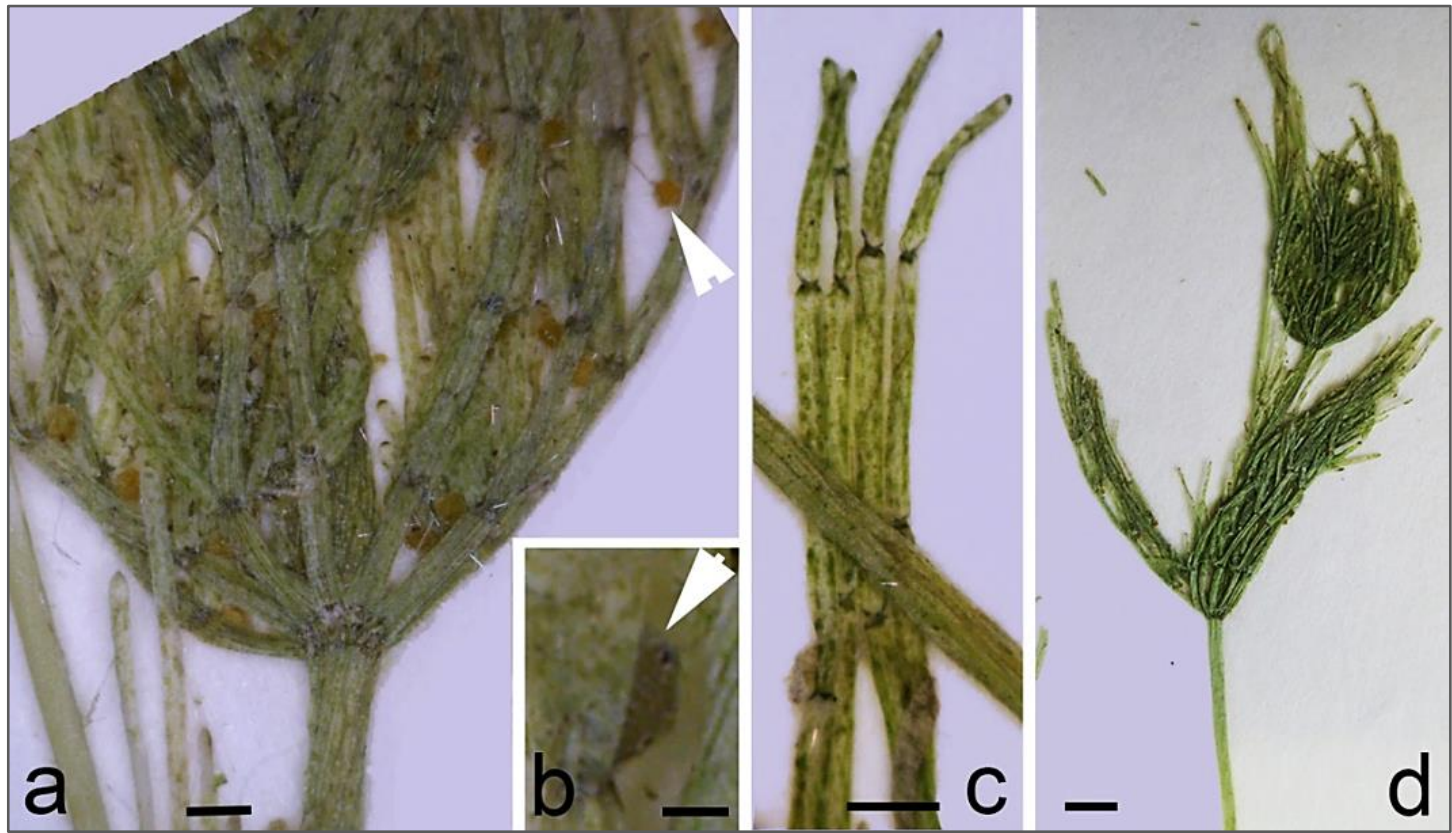

Figure 14. Chara vulgaris var. longibracteata (Kütz.) J. Gr. et B. Webst. from Dr. Lipkin collection: a - axis with stipulodes and base of whorl, antheridia pointed by white arrowhead; $b$ - oospore pointed by white arrowhead; $c$ - branches end cells; $d$ - view of thallus. Scale bars: $a-200$ um; $b-50$ um; c-50 um; $\mathrm{d}-1 \mathrm{~mm}$ 


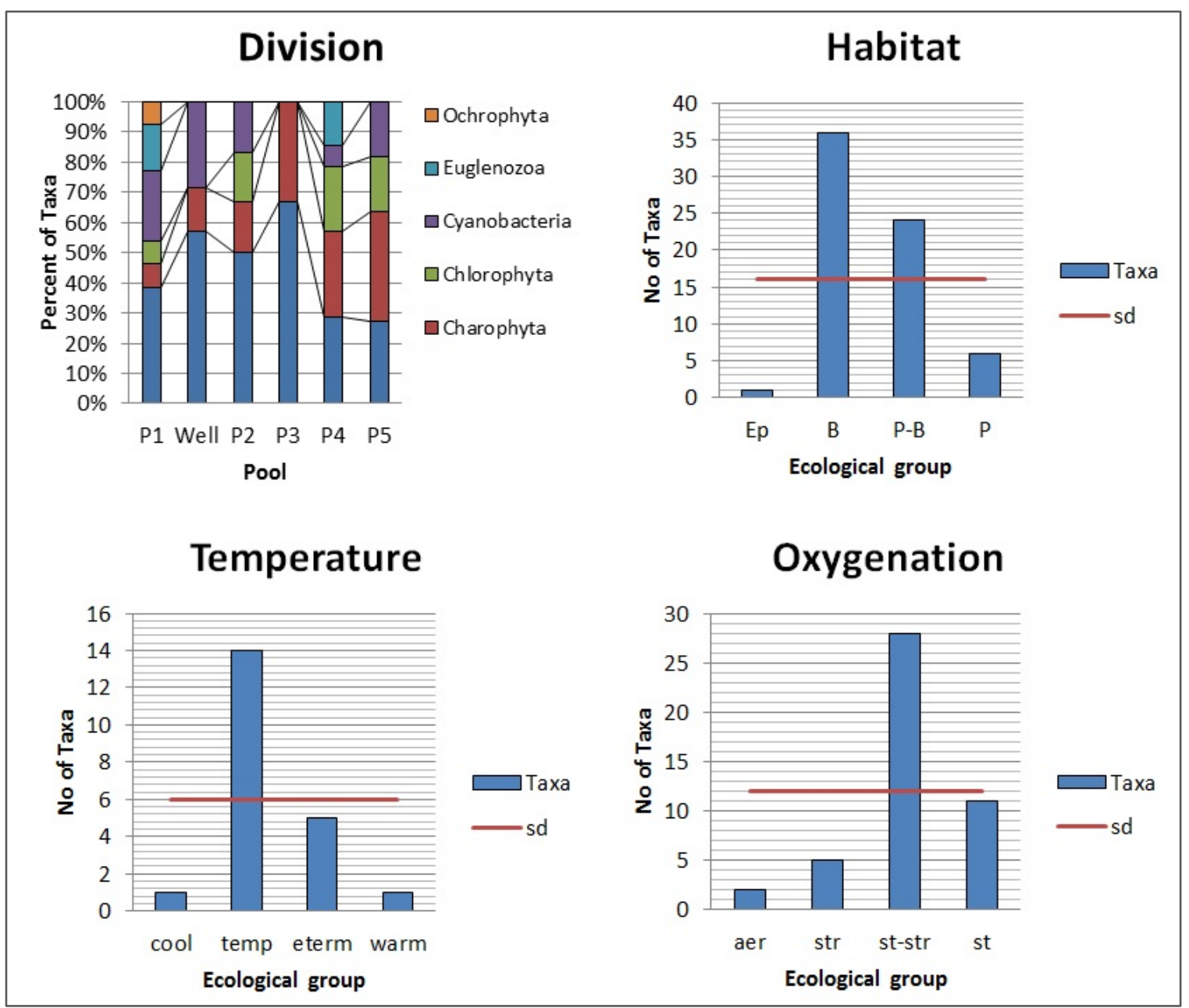

Figure 15. Taxonomic composition of algal communities and bio-indication in the pools of the Ein Afeq Natural Reserve 


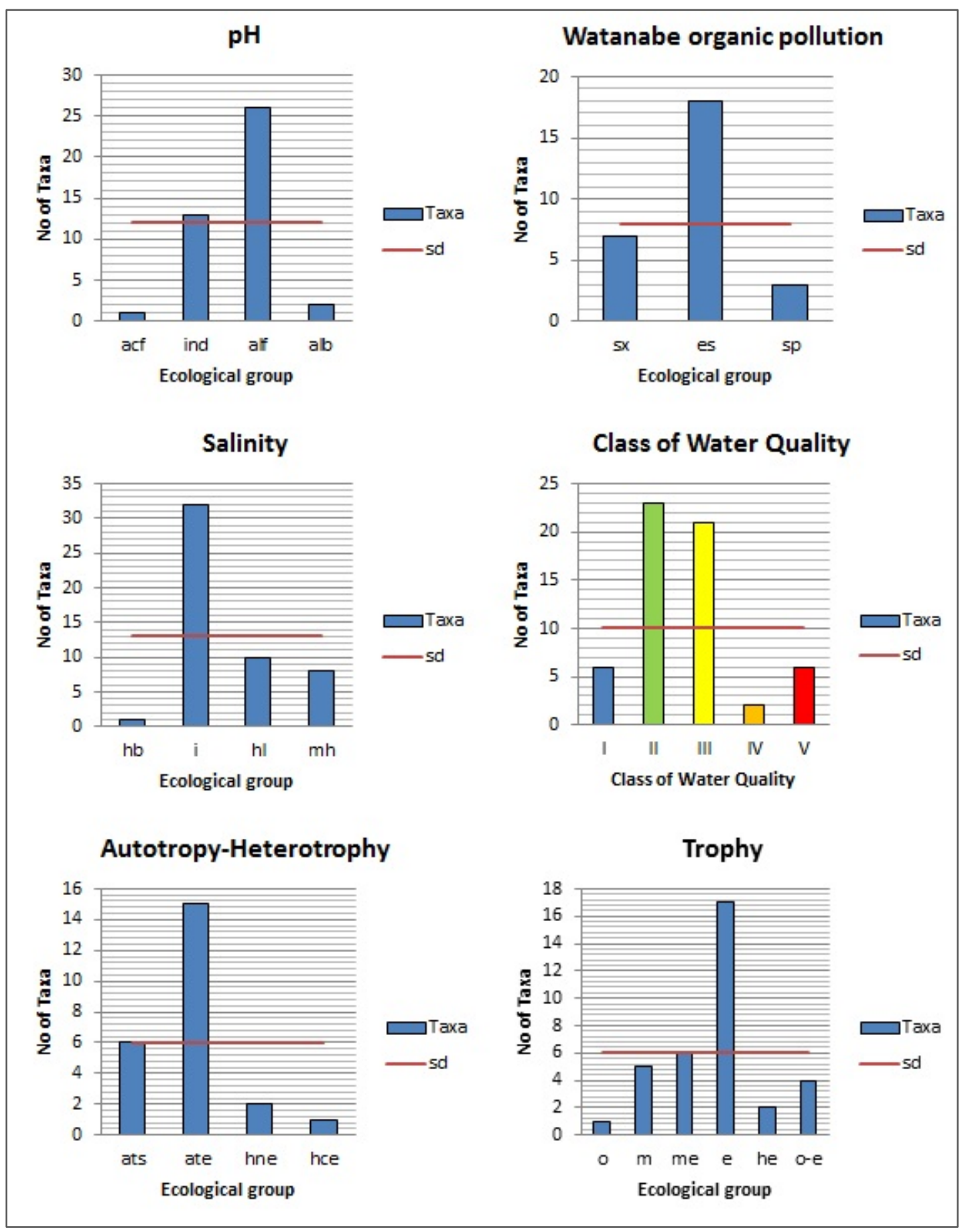

Figure 16. Bio-indication in the pools of the Ein Afeq Natural Reserve, where column in the plot of Class of Water Quality colored in European Standards

\subsection{Bio-indication of the Studied Pool Environment}

We use bio-indication methods in purpose to characterize of the studied pools water quality and ecosystem sustainable. As can be seen in Table 2, the water quality defined by bio-indication is the same that show by water chemistry (Table 1). In addition we can characterize the Ein Afeq Natural Reserve pools as low alkaline, fresh, eutrophic (Figure 16) with prevailing of organisms with autotrophic type of nutrition, which are mostly attached of substrate
(Figure 15) in moderate temperature medium oxygenated waters.

We calculated ecosystem state index WESI on the base of index Saprobity and nitrate-nitrogen concentration (Table 1). Can be seen that WESI is $0.40-0.80$ in pools 2,3 and 5 , that mean that its ecosystems are under some press may be as a result of the organic enrichments come from the catchment area as a result of recreation. Present of the anoxia indicator species cyanoprokaryote Pseudanabaena redeckei (Table 2) confirm that Pool 2, deepest, is under 
organic pollution impact. Pools 1, 4 and Well ecosystems are in good condition during study period. This situation is similar to that of the Upper Jordan River previously examined by us [18] where the pollution coming from the catchment area pollutes the water.

\section{Conclusions}

The Ein Afeq Natural Reserve pools as new studied locality in protected area of the Akko Plain in the Northern Israel can be characterize as natural, fresh, low alkaline with low-to-middle organic polluted waters that inhabit by seventy one algal species from which the streptophytes Chara vulgaris and C. connivens (Characeae) were found in well condition with attached mostly by diatoms. The both charophyte species are distributed over the Mediterranean phytogeographic realm and therefore can be used as distinct indicator of successional stage of aquatic ecosystem. The Ein Afeq pools ecosystem found as slightly impacted in few of them in a result of recreation. Therefore, the new charophyte locality in protected area of the Northern Israel can be monitored with using of chemical and bio-indication methods. It needs more attention to the pools management in purpose to protect from excessive recreation.

\section{Acknowledgements}

We thank Prof Yaakov Lipkin for collection of past samples, Dr Marcelo Sternberg for the possibility to study of herbarium specimens (TELA), Dr Sofa Marman, Svyatoslav, Nataly, Alex and George Rybnikov for their assistance in the field trip. This work was partly funded by the Israeli Ministry of Absorption and Israeli Taxonomic Initiative Fond, and Russian Foundation for Basic Research, project 14-04-31596-mol-a.

\section{REFERENCES}

[1] A. Pukacz, M. Pełechaty, A. Pełechata. The relation between charophytes and habitat differentiation in temperate lowland lakes. Polish Journal of Ecology, Vol. 61(1), 105-118, 2013.

[2] R. E. Romanov, S. S. Barinova. The charophytes of Israel: historical and contemporary species richness, distribution, and ecology, Biodiv. Res. Conserv., Vol.25, 57-64, 2012.

[3] S. Barinova, C.N. Solak, O. Erdoğan, R. Romanov. Algae and Zooplankton in Ecological Assessment of the Işıklı Lake, Turkey, Aquatic Biology Research, Vol.2, No.2, 23-35, 2014a.

[4] S. Barinova, R. Romanov, C.N. Solak. New record of Chara hispida (L.) Hartm. (Streptophyta: Charophyceae, Charales) from the Issıklı Lake (Turkey) and critical checklist of Turkish charophytes, Natural Resources and Conservation, Vol.2, No.3, 33-42, 2014b.

[5] D.M. John, B.A. Whitton, A.J. Brook (Eds.). The freshwater algal flora of the British Isles: an identification guide to freshwater and terrestrial algae, Cambridge University Press, Cambridge, 2011.

[6] W. Krause. Charales (Charophyceae). Süßwasserflora von Mitteleuropa, vol. 18, Gustav Fischer Verlag, Stuttgart, 1997.

[7] S.S. Barinova, L.A. Medvedeva, O.V. Anissimova. Diversity of algal indicators in environmental assessment. Pilies Studio, Tel Aviv, (Book in Russian with tables and annotation in English), 2006.

[8] E. Swift. Cleaning Diatom Frustules with Ultraviolet Radiation and Peroxide, Phycologia, Vol.6, No.2-3, 161-163, 1967.

[9] S. S. Barinova. Morphology of connective spines in diatom algae of the genus Aulacoseira Thwaites, Pa-leontological Journal, Vol.31, No.2, 239-245, 1997.

[10] V. Sládeček. Diatoms as indicators of organic pollution, Acta Hydroch. Hydrob., Vol.14, 555-566, 1986.

[11] S. Barinova. Algal diversity dynamics, ecological assessment, and monitoring in the river ecosystems of the eastern Mediterranean, Nova Science Publishers, New York, USA, $2011 b$.

[12] http://my-country-israel.com/en/Israel_Nature_and_Parks/N orth_(Kineret)/The_Ein_Afek_Nature_Reserve

[13] H. Van Dam, A. Martens, J. Sinkeldam. A coded checklist and ecological indicator values of freshwater diatoms from the Netherlands, Netherlands J. Aquatic Ecol., Vol.28, 117133, 1994.

[14] http://en.climate-data.org/location/708911/

[15] algaebase.org

[16] G. Yehuda, S.S. Barinova, T. Krugman, T. Pavlicek, Y. Nov, E. Nevo. Microscale adaptive response of charophytes of the Negev Desert, Israel: species divergences by AFLP, Natural Resources and Conservation Vol.1, No.3, 55-64, 2013.

[17] J.-C. Felzines, É. Lambert. Contribution au prodrome des végétations de France: les Charetea fragilis F. Fukarek 1961, J. Bot. Soc. Bot. France, Vol.59, 133-188, 2012.

[18] S. S. Barinova, E. Nevo. The Upper Jordan River algal communities are evidence of long-term climatic and anthropogenic impacts, J. Water Resource and Protection, Vol.2, 507-526, 2010. 